Papan Partikel dari Limbah Serutan Rotan

dan Cangkang Sawit.....Budi Tri Cahyana

\title{
PAPAN PARTIKEL DARI LIMBAH SERUTAN ROTAN DAN CANGKANG SAWIT
}

\author{
Particle Board from The Waste of Rattan Shaving and Oil Palm Shell
}

Budi Tri Cahyana

Balai Riset dan Standardisasi Industri Banjarbaru JI. P. Batur Barat No.2. Telp.0511-4772461-4774861

E-mail : baristand.banjarbaru@gmail.com

Diterima 04 Maret 2013, disetujui 01 Juni 2013

\begin{abstract}
ABSTRAK
Penelitian papan partikel untuk penggunaan dalam ruangan (Interior) dengan komposisi campuran partikel serutan rotan (sebagai inti) dan cangkang kelapa sawit (sebagai lapisan luar) telah dilakukan komposisi terdiri dari a1 $=30 \%: 40 \%: 30 \%$, a2 $=25 \%: 50 \%: 25 \%$, a3 = 20\%: $60 \%: 20 \%$, a4 $=15 \%: 70 \%: 15 \%$, a5 $=10 \%: 80 \%$ $: 10 \%, a 6=5 \%: 90 \%: 5 \%$. Konsentrasi perekat urea formaldehida (UF) b1=3\%, b2 = $6 \%$, b3 $=9 \%$. Hasil pengujian sifat fisik dan mekanik papan partikel menunjukkan kadar air $11,12 \%-11,71 \%$, pengembangan tebal 5,56 \% - 7,15\%, daya serap air 18,04 \% 23,46\%, kerapatan 0,52 $\mathrm{g} / \mathrm{cm}^{3}-0,71 \mathrm{~g} / \mathrm{cm}^{3}$, keteguhan lentur (MOE) $128 \mathrm{~kg} / \mathrm{cm}^{2}-697$ $\mathrm{kg} / \mathrm{cm}^{2}$ dan keteguhan patah (MOR) $52 \mathrm{~kg} / \mathrm{cm}^{2}-106 \mathrm{~kg} / \mathrm{cm}^{2}$. Semakin besar konsentrasi bahan baku serutan rotan maupun perekat UF dihasilkan kualitas papan partikel semakin baik, termasuk dalam kriteria papan partikel datar berkerapatan sedang. Papan partikel yang dihasilkan memenuhi Standar Nasional Indonesia untuk papan partikel datar SNI 03-2105-2006.
\end{abstract}

Kata kunci : papan partikel, serutan rotan, cangkang sawit

\section{ABSTRACT}

The research of particle board for interior purpose with the mixed composition of rattan shavings (as core) and oil palm shell (the outer layer) had been done. Those composition consisted of a1 $=30 \%: 40 \%: 30 \%$, a2 $=25 \%: 50 \%: 25 \%$, a3 $=20 \%, 60 \%, 20 \%$, $a 4=15 \%: 70 \%: 15 \%, a 5=10 \%: 80 \%, 10 \%, a 6=5 \%: 90 \%: 5 \%$. The concentration of Urea Formaldehida (UF) adhesive were $b 1=3 \%, b 2=6 \%, b 3=9 \%$. The physical and mechanical properties of particles board showed that water content 11,12\% - 11,71\%, the development of thickness 5,56\% - 7,15\%, water absorption $18,04 \%-23,46 \%$, density $0,52 \mathrm{~g} / \mathrm{cm}^{3}-0,71 \mathrm{~g} / \mathrm{cm}^{3}$, Modulus of Elasticity (MOE) $128 \mathrm{~kg} / \mathrm{cm}^{2}-697 \mathrm{~kg} / \mathrm{cm}^{2}$, Module of Rufture (MOR) $52 \mathrm{~kg} / \mathrm{cm}^{2}-106 \mathrm{~kg} / \mathrm{cm}^{2}$. The higher the concentration of raw materials of rattan shavings nor UF adhesive, the better quality of partcle board, included in the criteria for medium density of flat particle board. The resulted particle boards meet requirements of Indonesian National Standard for flat particle board SNI 03-2105-2006.

Keywords: particle board, rattan shaving, oil palm shell

\section{PENDAHULUAN}

Kebutuhan kayu struktural, papan dan lainnya untuk bahan bangunan gedung, perumahan semakin tahun semakin meningkat seiring dengan semakin meningkatnya perkembangan. Disisi lain ketersediaan kayu semakin berkurang, hal ini menuntut konsekuensi penghematan dan optimalisasi dalam pemakaian kayu serta pencarian bahan alternatif pengganti kayu. Bahan-bahan berupa limbah / hasil samping dari industri sangat besar dan sampai saat ini belum dimanfaatkan maksimal. Diantaranya limbah Industri pengolahan CPO (Crude Palm Oil) berupa cangkang kelapa sawit 
dan limbah industri pengolahan mebel rotan berupa serutan rotan. Bahan-bahan tersebut tergolong bahan berlignoselulosa yang merupakan material yang dapat dibuat sebagai bahan baku papan komposit. Indonesia mempunyai \pm 323 pabrik kelapa sawit (PKS) dengan asumsi setiap 5 ton tandan buah segar menghasilkan limbah padat 2,1 ton yang terdiri dari $950 \mathrm{~kg}$ fiber dan cangkang serta $1150 \mathrm{~kg}$ tandan kosong kelapa sawit (TKKS) (Distanbun, Dep.Tan, 2008) dalam Suroto (2010). Sedangkan limbah dari Industri perajin rotan berupa serutan rotan kurang lebih 347.256 ton/tahun. Dengan adanya potensi limbah yang sangat besar tersebut kemungkinan dapat dimanfaatkan sebagai bahan baku salah satu komponen bahan-bahan bangunan seperti papan partikel sekaligus meningkatkan daya guna atau nilai tambah dari limbah tersebut.

Papan partikel merupakan salah satu jenis produk komposit atau panel kayu yang terbuat dari partikel-partikel kayu atau bahan-bahan berlignoselulosa lainnya, yang diikat dengan perekat sintetis atau bahan pengikat lain kemudian dikempa panas (Maloney, 1993). Produk-produk komposit yang mana saat ini dalam penggunaannya menggantikan fungsi kayu padat dalam beberapa aplikasi misalnya untuk kontruksi ringan dan bahan baku mebel (Setiawan, 2008). Produk papan partikel ini dapat mengurangi pasokan kayu padat sebagai komponen bahan bangunan perumahan. Dalam penelitian ini dilakukan pembuatan papan partikel dari limbah serutan rotan dan cangkang kelapa sawit untuk penggunaan dalam ruangan (interior) seperti produk lemari, meja, rak buku, dinding penyekat ruangan dan lain-lain.

\section{BAHAN DAN METODE}

Bahan penelitian meliputi serutan rotan, cangkang kelapa sawit, urea formaldehida (UF), kertas aluminium foil. Peralatan meliputi satu set alat cetak berukuran $30 \times 30 \times 6 \mathrm{~cm}$, gergaji mesin, mesin press, peralatan uji mekanik (Universal Testing Machine (UTM)).

Persiapan bahan baku serutan rotan dipotong panjang $5 \mathrm{~cm}$, cangkang kelapa sawit digiling diayak lolos 16 mesh, masing-masing direndam dalam air kemudian dicuci sampai bekas air cucian tidak kotor (jernih). Kemudian dijemur sampai kering (diperoleh kadar air antara 5 sampai $10 \%$ ). Papan komposit dibuat dengan ukuran (panjang $\mathrm{x}$ lebar $\mathrm{x}$ tebal) $=$ $30 \mathrm{~cm} \times 30 \mathrm{~cm} \times 1,5 \mathrm{~cm}$. Bahan-bahan sesuai perlakuan dimasukkan dalam alat cetak kemudian dipres dingin dilanjutkan panas suhu $120{ }^{\circ} \mathrm{C}$ selama \pm 15 menit (tekanan kempa $\pm 40 \mathrm{~kg} / \mathrm{cm} 2$ ), sampai diperoleh tebal papan partikel $\pm 1,5 \mathrm{~cm}$. Setelah dingin dikeluarkan dari alat cetak, selanjutnya dikondisikan dalam ruangan suhu kamar. Selanjutnya dilakukan pengujian fisik dan mekanik yang mengacu pada standar uji papan partikel datar (SNI.01-2105-2006) meliputi kadar air, pengembangan tebal, daya serap air, kerapatan, modulus elastisitas (MOE) dan modulus patah (MOR).

\section{HASIL DAN PEMBAHASAN}

Nilai rata-rata pengujian sifat fisik papan partikel yang meliputi kadar air dan pengembangan tebal dapat dilihat pada Tabel 1.

Tabel 1. Nilai Rata-rata Kadar Air dan Pengembangan Tebal

\begin{tabular}{ccccccc}
\hline \multirow{3}{*}{$\begin{array}{c}\text { Komposisi } \\
\text { C Swt : Rtn : } \\
\text { C Swt }\end{array}$} & \multicolumn{3}{c}{ Kadar Air (\%) } & \multicolumn{3}{c}{$\begin{array}{c}\text { Pengembangan Tebal } \\
(\%)\end{array}$} \\
\cline { 2 - 7 } & $\begin{array}{c}\text { Konsentrasi Perekat UF } \\
(\%)\end{array}$ & $\begin{array}{c}\text { Konsentrasi Perekat UF } \\
(\%)\end{array}$ \\
\cline { 2 - 7 } & $\mathrm{b}_{1}=3$ & $\mathrm{~b}_{2}=6$ & $\mathrm{~b}_{3}=9$ & $\mathrm{~b}_{1}=3$ & $\mathrm{~b}_{2}=6$ & $\mathrm{~b}_{3}=9$ \\
\hline $30: 40: 30(\mathrm{a} 1)$ & 11,71 & 11,68 & 11,61 & 7,15 & 7,03 & 6,82 \\
\hline $25: 50: 25(\mathrm{a} 2)$ & 11,51 & 11,50 & 11,48 & 6,73 & 6,66 & 6,50 \\
\hline $20: 60: 20(\mathrm{a} 3)$ & 11,46 & 11,44 & 11,38 & 6,49 & 6,32 & 6,05 \\
\hline $15: 70: 15(\mathrm{a} 4)$ & 11,36 & 11,35 & 11,34 & 6,23 & 6,15 & 5,87 \\
\hline $10: 80: 10(\mathrm{a} 5)$ & 11,30 & 11,29 & 11,26 & 6,00 & 5,96 & 5,70 \\
\hline $5: 90: 5(\mathrm{a} 6)$ & 11,15 & 11,15 & 11,12 & 5,75 & 5,61 & 5,56 \\
\hline & & & & & &
\end{tabular}

\subsection{Kadar Air}

Berdasarkan pada Tabel 1, dapat dikemukakan nilai kadar air rata-rata dari papan partikel berkisar antara 11,12\% $11,71 \%$. Di dalam standar nasional (SNI 03-2105-2006) kadar air papan partikel datar ditetapkan tidak lebih dari $14 \%$. Dengan demikian nilai kadar air papan partikel hasil penelitian memenuhi standar papan partikel. Nilai kadar air terendah pada komposisi cangkang sawit $10 \%$, serutan rotan $90 \%$ dan perekat UF 
9\% (a6b3). Sedangkan nilai tertinggi pada komposisi cangkang sawit $60 \%$, serutan rotan $40 \%$ dan perekat UF 3\% (a1b1). Hasil ini menunjukkan bahwa semakin besar persentase bahan baku dari serutan rotan dan perekat, semakin kecil persentase cangkang sawit maka nilai kadar air papan partikel semakin kecil (rendah) hal ini memberikan informasi bahwa kualitas papan partikel yang dihasilkan menunjukkan kualitasnya semakin lebih baik.

Tabel 2. Analisa Keragaman Kadar Air Papan Partikel

\begin{tabular}{ccccccc}
\hline \multirow{2}{*}{$\begin{array}{c}\text { Sumber } \\
\text { Keragaman }\end{array}$} & DB & JK & KT & F. Hit & \multicolumn{2}{c}{ F. Tabel } \\
\cline { 5 - 7 } & & & & & $05 \%$ & $0,01 \%$ \\
\hline Perlakuan & 17 & 2,3992 & 0,1411 & 1,58 & 1,84 & 2,37 \\
A & 5 & 1,0458 & 0,2092 & 2,35 & 2,45 & 3,51 \\
B & 2 & 0,0733 & 0,0366 & 0,21 & 3,23 & 5,18 \\
AB & 10 & 0,3905 & 0,0325 & 1,12 & 2,08 & 2,80 \\
Galat & 36 & 3,2061 & 0,089 & & & \\
\hline
\end{tabular}

Berdasarkan uji keragaman pada Tabel 2 menunjukkan bahwa perlakuan variasi komposisi bahan baku cangkang kelapa sawit dan serutan rotan serta perekat Urea formaldehida (UF) tidak berpengaruh terhadap nilai kadar air. Apri Heri Iswanto (2008) menyebutkan bahwa kadar air papan partikel tergantung pada kondisi udara sekitarnya, karena papan partikel terdiri atas bahan-bahan yang mengandung lignoselulosa sehingga papan partikel bersifat higroskopis. Semakin halus butir-butir padatan semakin banyak air yang teradsorbsi, karena luas permukaan per satuan berat bertambah (Putri MD, 2002). Haygreen dan Bowyer (1996) menyebutkan produk papan partikel yang menggunakan bahan baku berkerapatan rendah sampai sedang mudah dikempa akibatnya kontak antara permukaan partikel semakin sempurna dan panel yang dibentuk semakin padat sehingga kekuatannya semakin baik. Sehingga kemampuan untuk menyerap air semakin baik (semakin kecil).

\subsection{Pengembangan Tebal}

Berdasarkan pada Tabel 1, dapat dikemukakan nilai rata - rata pengembangan tebal dari papan partikel berkisar antara 5,56 \% - 7,15\%. Didalam
Standar Nasional Indonesia (SNI 03-21052006) pengembangan tebal papan partikel ditetapkan maksimal sebesar $20 \%$. Dengan demikian nilai pengembangan tebal papan partikel memenuhi standar papan partikel. Nilai terendah pada komposisi bahan cangkang sawit 10\%, serutan rotan $90 \%$ dengan perekat UF $9 \%$ (a6b3), sedangkan yang tertinggi pada komposisi bahan cangkang sawit 60\%, serutan rotan $40 \%$ dengan perekat UF $3 \%$ (a1b1). Hal ini menyatakan bahwa semakin kecil pengembangan tebal kualitas papan partikel semakin baik. Dari data hasil penelitian menunjukkan bahwa semakin banyak bahan baku serutan rotan dan semakin tinggi konsentrasi perekat maka nilai persentase pengembangan tebal semakin kecil, sebaliknya semakin banyak bahan baku dari cangkang sawit dan semakin kecil persentase perekat maka nilai persentase pengembangan tebal semakin besar.

Tabel 3. Analisa Keragaman Pengembangan Tebal

\begin{tabular}{ccccccc}
\hline $\begin{array}{c}\text { Sumber } \\
\text { Keragaman }\end{array}$ & DB & JK & KT & F. Hit & \multicolumn{2}{c}{ F. Tabel } \\
\hline Perlakuan & 17 & 12,1381 & 0,7140 & $41,5^{* *}$ & 1,84 & $2,01 \%$ \\
A & 5 & 11,1661 & 2,2332 & $129,8^{* *}$ & 2,45 & 3,51 \\
B & 2 & 0,8866 & 0,4433 & $25,8^{* *}$ & 3,23 & 5,18 \\
AB & 10 & 0,0854 & 0,0071 & 0,41 & 2,08 & 2,80 \\
Galat & 36 & 0,6194 & 0,0172 & & & \\
\hline \multicolumn{3}{l}{ Keterangan : " berpengaruh sangat nyata } & &
\end{tabular}

Berdasarkan analisis keragaman pada Tabel 3 perlakuan A (kombinasi bahan baku) dan B (konsentrasi perekat UF) berpengaruh sangat nyata dan dari uji beda nilai rata-rata perlakuan $A$ dan $B$ menunjukkan perbedaan yang sangat nyata terhadap pengembangan tebal papan partikel yang dihasilkan, semakin tinggi persentase serutan rotan dan perekat (UF) menunjukkan semakin rendah nilai pengembangan tebal. Hal demikian disebabkan faktor - faktor antara lain perbedaan jenis bahan baku, keseragaman dalam proses pencampuran perekat, dan juga semakin banyak bahan serutan rotan mengakibatkan semakin luasnya permukaan / bidang saling kait mengait antar partikel, dan dengan semakin tinggi konsentrasi perekat serta adanya pengepresan / penekanan panas, maka 
dimensi papan semakin kompak / padat (rapat). Sebaliknya semakin banyak bahan cangkang sawit maka semakin rendah saling keterkaitan antar partikel dan ditunjang kecilnya konsentrasi perekat maka dimensi papan semakin buruk/ kurang stabil, mudah menyerap air / udara lingkungan sehingga papan lebih mudah mengembang.

Menurut Dirhamsyah dalam Praguna (2008) menyatakan bahwa pengembangan tebal papan partikel merupakan gabungan dua komponen yaitu dari partikel itu sendiri dan pengembangan akibat dari pembebasan tegangan tekan, ini terjadi pada saat kadar air tinggi dan bagian pengembangan ini tidak dapat pulih kembali apabila papan partikel telah mengalami pengeringan. Berat jenis bahan baku juga sangat berpengaruh terhadap pengembangan tebal. Hasil penelitian Hamdi S. (2010), menyatakan bahwa papan partikel yang terbuat dari bahan yang memiliki berat jenis rendah mempunyai sifat pengembangan tebal yang cenderung lebih besar dari bahan yang mempunyai berat jenis tinggi. Hal lain yang dapat mempengaruhi pengembangan tebal adalah jenis perekat UF yang memiliki sifat labil sehingga lebih mudah dimasuki oleh air, sehingga jenis perekat UF cocok untuk perekat jenis interior.

\subsection{Daya Serap Air}

Tabel 4. Nilai Rata-rata Daya Serap Air Dan Kerapatan

\begin{tabular}{|c|c|c|c|c|c|c|}
\hline \multirow{3}{*}{$\begin{array}{c}\text { Komposisi } \\
\text { C Swt : Rtn : C } \\
\text { Swt }\end{array}$} & \multicolumn{3}{|c|}{ Daya Serap Air (\%) } & \multicolumn{3}{|c|}{ Kerapatan $\left(\mathrm{g} / \mathrm{cm}^{2}\right)$} \\
\hline & \multicolumn{3}{|c|}{$\begin{array}{c}\text { Konsentrasi Perekat } \\
\text { UF }(\%)\end{array}$} & \multicolumn{3}{|c|}{$\begin{array}{c}\text { Konsentrasi Perekat } \\
\text { UF (\%) }\end{array}$} \\
\hline & $b_{1}=3$ & $b_{2}=6$ & $b_{3}=9$ & $b_{1}=3$ & $b_{2}=6$ & $b_{3}=9$ \\
\hline $30: 40: 30$ (a1) & 23,46 & 22,47 & 21,63 & 0,52 & 0,59 & 0,66 \\
\hline $25: 50: 25$ (a2) & 22,40 & 21,53 & 20,68 & 0,55 & 0,60 & 0,67 \\
\hline $20: 60: 20$ (a3) & 21,99 & 20,84 & 19,73 & 0,55 & 0,61 & 0,68 \\
\hline $15: 70: 15(\mathrm{a} 4)$ & 21,39 & 20,14 & 19,51 & 0,57 & 0,64 & 0,69 \\
\hline $10: 80: 10(\mathrm{a} 5)$ & 20,92 & 19,46 & 18,77 & 0,57 & 0,64 & 0,69 \\
\hline $5: 90: 5(\mathrm{a} 6)$ & 20,09 & 19,15 & 18,04 & 0,57 & 0,65 & 0,71 \\
\hline
\end{tabular}

Berdasarkan pada Tabel 4, dapat dikemukakan nilai rata-rata daya serap air dari papan partikel menunjukkan bahwa nilai daya serap air tertinggi $23,46 \%$ pada perlakuan cangkang sawit $60 \%$, serutan rotan $40 \%$ dan perekat UF $3 \%$ (a1b1). Sedang terendah $18,04 \%$ pada perlakuan cangkang sawit $10 \%$, serutan rotan $90 \%$ dan perekat UF 9\% (a6b3). Semakin banyak bahan baku serutan rotan dan semakin tinggi konsentrasi perekat maka nilai persentase daya serap air semakin rendah hal demikian kualitas papan partikel semakin baik, sebaliknya semakin banyak bahan baku dari cangkang sawit dan semakin kecil persentase perekat maka nilai persentase daya serap air semakin rendah hal demikian kualitas papan partikel semakin buruk. Daya serap air berbanding lurus dengan kadar air artinya semakin kecil kandungan air maka daya atau kemampuan untuk menyerap air juga semakin kecil. Berbanding terbalik dengan nilai kerapatan artinya semakin tinggi nilai kerapatan semakin kecil daya kemampuan untuk meyerap air.

Tabel 5. Analisa Keragaman Daya Serap Air

\begin{tabular}{c|c|r|r|c|c|c}
\hline Sumber & \multirow{2}{*}{ Su } & \multirow{2}{*}{ JK } & \multirow{2}{*}{ KT } & F. Hit & \multicolumn{2}{|c}{ F. Tabel } \\
\cline { 5 - 7 } Keragaman & & & & & $0,05 \%$ & $0,01 \%$ \\
\hline Perlakuan & 17 & 107,613 & 6,33 & $631,5^{* *}$ & 1,84 & 2,37 \\
A & 5 & 69,39 & 13,88 & $1384^{* *}$ & 2,45 & 3,51 \\
B & 2 & 35,53 & 17,76 & $1772^{* *}$ & 3,23 & 5,18 \\
AB & 10 & 2,5021 & 0,2085 & $20,8^{* *}$ & 2,08 & 2,80 \\
Galat & 36 & 0,3608 & 0,01 & & & \\
\hline
\end{tabular}

Keterangan : " berpengaruh sangat nyata

Berdasarkan analisis keragaman pada Tabel 5, perlakuan A (kombinasi bahan baku) dan B (konsentrasi perekat UF) berpengaruh sangat nyata dan dari uji beda nilai rata-rata antar perlakuan interaksi $A B$ menunjukkan perbedaan yang sangat nyata terhadap daya serap air pada papan partikel yang dihasilkan.

\subsection{Kerapatan}

Berdasarkan pada Tabel 5, dapat dikemukakan nilai rata-rata kerapatan dari papan partikel berkisar dari $0,52 \mathrm{~g} / \mathrm{cm}^{3}$ sampai $0,71 \mathrm{~g} / \mathrm{cm}^{3}$. Didalam Standar Nasional Indonesia (SNI 03-2105-2006) kerapatan papan partikel ditetapkan antara $0,4 \mathrm{~g} / \mathrm{cm}^{3}$ sampai $0,9 \mathrm{~g} / \mathrm{cm}^{3}$. Dengan demikian nilai kerapatan papan partikel memenuhi standar papan partikel. Dari Tabel 5, menunjukkan bahwa nilai kerapatan tertinggi $0,71 \mathrm{~g} / \mathrm{cm}^{3}$ pada perlakuan a6b3 (cangkang sawit 10\%, serutan rotan $90 \%$ dan perekat UF $9 \%$ ). Sedang terendah $0,52 \mathrm{~g} / \mathrm{cm}^{3}$ pada perlakuan a1b1 (cangkang sawit $60 \%$, serutan rotan $40 \%$ dan perekat UF $3 \%$ ). Semakin banyak bahan baku serutan rotan 
dan semakin tinggi konsentrasi perekat maka nilai kerapatan papan partikel semakin tinggi hal demikian kualitas papan partikel semakin baik, sebaliknya semakin banyak bahan baku dari cangkang sawit dan semakin kecil persentase perekat maka nilai kerapatan semakin kecil. Nilai kerapatan merupakan salah satu indikator penting bagi kualitas papan partikel. Maloney (1993) menyatakan bahwa kerapatan sangat mempengaruhi kebanyakan sifat-sifat papan komposit, peningkatan kerapatan akan memperbaiki hampir semua sifat papan komposit kecuali stabilitas dimensi. Ditinjau dari nilai kerapatannya maka papan partikel hasil penelitian masuk kategori kerapatan sedang, sesuai pernyataan Paribotro $S$ dan Adi Santoso (1991) dalam Hamdi S (2010) papan partikel berkerapatan sedang dengan kisaran nilai kerapatan antara $0,40-0,80 \mathrm{gr} / \mathrm{cm}^{3}$ bahwa papan partikel berkerapatan sedang dapat digunakan untuk bahan baku meubel seperti bagian atas produk lemari, meja, tempat buku, rak buku dan lain-lain.

Tabel 6. Analisa Keragaman Kerapatan

\begin{tabular}{ccclccc}
\hline Sumber & \multirow{2}{*}{ DB } & \multirow{2}{*}{ JK } & \multirow{2}{*}{ KT } & F. Hit & \multicolumn{2}{c}{ F. Tabel } \\
\cline { 6 - 7 } Keragaman & & & & & $0,05 \%$ & $0,01 \%$ \\
\hline Perlakuan & 17 & 0,1037 & 0,0061 & 1,61 & 1,84 & 2,37 \\
A & 5 & 0,0182 & 0,0036 & 0,95 & 2,45 & 3,51 \\
B & 2 & 0,0198 & 0,0099 & 2,60 & 3,23 & 5,18 \\
AB & 10 & 0,0015 & 0,000125 & 0,033 & 2,08 & 2,80 \\
Galat & 36 & 0,1363 & 0,0038 & & & \\
\hline
\end{tabular}

Berdasarkan uji keragaman pada Tabel 6, menunjukkan bahwa perlakuan variasi komposisi bahan baku cangkang kelapa sawit dan serutan rotan serta perekat Urea formaldehida (UF) tidak berpengaruh terhadap nilai kerapatan papan partikel komposit yang dihasilkan.

\subsection{Keteguhan Lentur (MOE)}

Berdasarkan pada Tabel 7 , dapat dikemukakan nilai rata-rata keteguhan lentur (MOE) dari papan partikel menunjukkan bahwa nilai keteguhan lentur (MOE) tertinggi pada perlakuan 10\% cangkang sawit, $90 \%$ serutan rotan dan $9 \%$ UF (a6b3) yaitu $697 \mathrm{~kg} / \mathrm{cm}^{2}$. Sedang terendah pada perlakuan $60 \%$ cangkang sawit, $40 \%$ serutan rotan dan 3\% UF (a1b1) yaitu $128 \mathrm{~kg} / \mathrm{cm}^{2}$.
Tabel 7. Nilai Rata-rata Keteguhan Lentur Dan Keteguhan Patah

\begin{tabular}{|c|c|c|c|c|c|c|}
\hline \multirow{3}{*}{$\begin{array}{c}\text { Komposisi } \\
\text { C Swt : Rtn : C Swt }\end{array}$} & \multirow{2}{*}{\multicolumn{3}{|c|}{$\begin{array}{c}\begin{array}{c}\text { Keteguhan Lentur } \\
\left(\mathrm{kg} / \mathrm{cm}^{2}\right)\end{array} \\
\text { Konsentrasi Perekat } \\
\text { UF (\%) }\end{array}$}} & \multicolumn{3}{|c|}{$\begin{array}{c}\text { Keteguhan Patah } \\
\left(\mathrm{kg} / \mathrm{cm}^{2}\right)\end{array}$} \\
\hline & & & & \multicolumn{3}{|c|}{$\begin{array}{c}\text { Konsentrasi Perekat } \\
\text { UF (\%) }\end{array}$} \\
\hline & $b_{1}=3$ & $b_{2}=6$ & $b_{3}=3$ & $b_{1}=3$ & $b_{2}=6$ & b3 $=9$ \\
\hline $30: 40: 30 \quad(a 1)$ & 128 & 178 & 195 & 52 & 63 & 75 \\
\hline $25: 50: 25(\mathrm{a} 2)$ & 215 & 244 & 265 & 57 & 67 & 80 \\
\hline $20: 60: 20(\mathrm{a} 3)$ & 322 & 340 & 359 & 63 & 75 & 86 \\
\hline $15: 70: 15(\mathrm{a} 4)$ & 435 & 462 & 480 & 69 & 81 & 90 \\
\hline $10: 80: 10(a 5)$ & 557 & 570 & 588 & 75 & 86 & 99 \\
\hline $5: 90: 5(a 6)$ & 669 & 683 & 697 & 83 & 95 & 106 \\
\hline
\end{tabular}

Semakin banyak bahan baku serutan rotan dan semakin tinggi konsentrasi perekat maka nilai persentase keteguhan lentur (MOE) semakin tinggi hal demikian kualitas papan partikel semakin baik, sebaliknya semakin banyak bahan baku dari cangkang sawit dan semakin kecil persentase perekat maka nilai keteguhan lentur semakin kecil. Didalam Standar Nasional Indonesia

(SNI 03-2105-2006) keteguhan lentur (MOE) papan partikel datar ditetapkan minimal $100 \mathrm{~kg} / \mathrm{cm}^{2}$, dengan demikian nilai keteguhan lentur (MOE) papan partikel memenuhi standar papan partikel.

Tabel 8. Analisa Keragaman Keteguhan Lentur

\begin{tabular}{ccccccc}
\hline $\begin{array}{c}\text { Sumber } \\
\text { Keragaman }\end{array}$ & DB & \multirow{2}{*}{ JK } & KT & F. Hit & \multicolumn{2}{c}{ F. Tabel } \\
\cline { 6 - 7 } & & & & $0,05 \%$ & $0,01 \%$ \\
\hline Perlakuan & 17 & 1777567 & 104563 & $4838^{* *}$ & 1,84 & 2,37 \\
A & 5 & 1758745 & 351749 & $16276^{* *}$ & 2,45 & 3,51 \\
B & 2 & 16802 & 8401 & $309^{* *}$ & 3,23 & 5,18 \\
AB & 10 & 2020 & 168,3 & $7,79^{* *}$ & 2,08 & 2,80 \\
Galat & 36 & 21,61 & 21,61 & & & \\
\hline
\end{tabular}

Keterangan : "berpengaruh sangat nyata

Berdasarkan analisis keragaman pada Tabel 8, perlakuan A (kombinasi bahan baku) dan B (konsentrasi perekat UF) berpengaruh sangat nyata dan dari hasil uji beda nilai rata-rata antar perlakuan interaksi $A B$ menunjukkan perbedaan yang sangat nyata terhadap nilai keteguhan lentur (MOE) papan partikel yang dihasilkan. Peningkatan nilai keteguhan lentur (MOE) pada papan partikel ini disebabkan bentuk partikel serutan rotan yang lebih panjang dibanding bentuk partikel cangkang sawit, sehingga memberikan peluang semakin luasnya permukaan / bidang saling kait mengait antar partikel, dan juga semakin tinggi konsentrasi perekat serta adanya proses pengepresan / penekanan panas, maka 
dimensi papan partikel semakin kompak/ padat (rapat), hal ini menyebabkan peningkatan sifat mekanis papan partikel. Hal ini sesuai dengan hasil penelitian Suroto (2010) bahwa panjang partikel serutan rotan $5 \mathrm{~cm}$ dan $9 \%$ perekat UF diperoleh kualitas papan partikel terbaik. Hasil ini juga erat kaitannya dengan komposisi kimia rotan yaitu sellulosa $39-58 \%$ dan lignin $18-21 \%$, kedua jenis bahan tersebut dapat meningkatkan kekuatan mekanis karena adanya ikatan kovalen yang kuat. Semakin tinggi kadar lignin semakin kuat rotan tersebut (Rahman H, 2006).

\subsection{Keteguhan Patah (MOR)}

Berdasarkan pada Tabel 7, dapat dikemukakan nilai rata-rata keteguhan patah (MOR) dari papan partikel komposit berkisar antara $52 \mathrm{~kg} / \mathrm{cm}^{2}-106 \mathrm{~kg} / \mathrm{cm} 2$. Nilai keteguhan patah (MOR) tertinggi 106 $\mathrm{kg} / \mathrm{cm} 2$ pada perlakuan $10 \%$ cangkang sawit, $90 \%$ serutan rotan dan 9\% UF (a6b3). Sedang terendah $52 \mathrm{~kg} / \mathrm{cm} 2$ pada perlakuan a1b1 (60\% cangkang sawit, $40 \%$ serutan rotan dan 3\% UF (a1b1). Sama halnya dengan nilai keteguhan lentur bahwa semakin banyak bahan baku serutan rotan dan semakin tinggi konsentrasi perekat maka nilai persentase keteguhan patah (MOR) juga semakin tinggi hal demikian menunjukkan kualitas papan com-ply semakin baik, sebaliknya semakin banyak bahan baku dari cangkang sawit dan semakin kecil persentase perekat maka nilai keteguhan patah semakin kecil.

Tabel 9. Analisa Keragaman Keteguhan Patah

\begin{tabular}{cccccccc}
\hline $\begin{array}{c}\text { Sumber } \\
\text { Keragaman }\end{array}$ & DB & \multirow{2}{*}{ JK } & KT & F. Hit & \multicolumn{2}{c}{ F. Tabel } \\
\cline { 6 - 8 } & & & & & $0,05 \%$ & $0,01 \%$ \\
\hline Perlakuan & 17 & 10859,3 & 638,78 & $27,2^{* *}$ & 1,84 & 2,37 \\
A & 5 & 6147,3 & 12298,5 & $52,3^{* *}$ & 2,45 & 3,51 \\
B & 2 & 4692,3 & 2346,3 & $99,8^{* *}$ & 3,23 & 5,18 \\
AB & 10 & 19,7 & 1,642 & 0,07 & 2,08 & 2,80 \\
Galat & 36 & 846 & 23,5 & & & \\
\hline \multicolumn{3}{r}{ Keterangan : "berpengaruh sangat nyata }
\end{tabular}

Berdasarkan analisis keragaman pada Tabel 9, perlakuan A (kombinasi bahan baku) dan B (konsentrasi perekat UF) berpengaruh sangat nyata dan dari hasil uji beda nilai rata-rata antar perlakuan interaksi $A B$ menunjukkan perbedaan yang sangat nyata terhadap nilai keteguhan patah (MOR) papan partikel yang dihasilkan.

Seperti halnya keteguhan lentur, peningkatan nilai keteguhan patah (MOR) pada papan partikel ini disebabkan bentuk partikel serutan rotan yang lebih panjang dibanding bentuk partikel cangkang sawit, sehingga memberikan peluang semakin luasnya permukaan/ bidang saling kait mengait antar partikel dan semakin tinggi konsentrasi perekat serta adanya proses pengepresan / penekanan panas, maka dimensi papan partikel semakin kompak/ padat (rapat), hal ini menyebabkan peningkatan sifat mekanis papan partikel. Hal ini sesuai dengan hasil penelitian Suroto (2010) bahwa panjang partikel serutan rotan $5 \mathrm{~cm}$ dan $9 \%$ perekat UF diperoleh kualitas papan partikel terbaik. Hasil ini juga erat kaitannya dengan komposisi kimia rotan yaitu sellulosa $39-58 \%$ dan lignin $18-21 \%$, kedua jenis bahan tersebut dapat meningkatkan kekuatan mekanis karena adanya ikatan kovalen yang kuat. Semakin tinggi kadar lignin semakin kuat rotan tersebut (Rahman, 2006).

\section{KESIMPULAN}

Semakin banyak limbah serutan rotan dan semakin tinggi konsentrasi perekat, mutu papan partikel semakin baik, demikian juga sebaliknya semakin banyak limbah cangkang kelapa sawit dan semakin kecil konsentrasi perekat, mutu papan partikel semakin rendah.

Papan partikel yang dibuat termasuk kriteria berkerapatan sedang, penggunaannya dari uji sifat fisik dan mekanik papan partikel memenuhi standar mutu papan partikel datar (SNI 03-21052006). Papan partikel terbaik dihasilkan pada perlakuan cangkang sawit : serutan rotan : cangkang sawit = $5 \%: 90 \%: 5 \%$, perekat $=9 \%$, atau perlakuan $(a 6 b 3)$.

\section{DAFTAR PUSTAKA}

1. Anonim, 2006. Standar Nasional Indonesia - SNI No. 03-2105-2006. Badan Standardisasi Indonesia. Jakarta. 
2. Haygreen, J.C and J.M Bowyer, 1996. Forest Product and Wood Science An Introduction. Loa State University, Loa.

3. Haygreen, J.C and J.M Bowyer, 1996. Hasil Hutan Dan Kayu, Suatu pengantar Terjemahan. Gajah Mada University Press. Yogyakarta.

4. Hamdi, S. 2010. Pengaruh Variasi Partikel Dari Beberapa Jenis Kayu Terhadap Sifat Fisik Mekank Papan Partikel. Hasil Litbang. Balai Reset Dan Standardisasi Industri Banjarbaru.

5. Masganti, $1988 . \quad$ Rancangan Percobaan. Universitas Islam Kalimantan (UNISKA) Muhammad Arsyad Al Banjari, Fakultas Pertanian Jurusan Peternakan, Banjarbaru. Kalimantan Selatan.

6. Paribotro, dkk, 1979. Pengaruh Jenis Kayu dan Campurannya Terhadap Beberapa Sifat Papan partikel. Lap. No. $144 \mathrm{LPHH}$. Dep. Kehutanan Bogor.

7. Praguna, 2008. Sifat Fisik Dan Mekanik Papan Partikel Dari Limbah Plastik Jenis HDPE ( High Density Polyethylene). Skripsi. Fakultas Kehutanan Unlam. Banjarbaru. Tidak Dipublikasikan

8. Putri MD. (2002). Peningkatan Mutu Papan Partikel dari Limbah Serbuk Gergaji Kayu Sengon (Paraserianthes Falcataria) dan Limbah Plastic Polypropylene: Peranan Maleic Anhidryde sebagai Compatibilizer (Skripsi). Bogor. Jurusan THH. Fakultas Kehutanan IPB. Bogor.

9. Rahman H (2006). Pembuatan Pulp dari Batang Pisang Uter (Musa Paradisiaca Linn Var Uter). Pascapanen dengan Proses Soda. Skripsi, Fakultas Kehutanan Yogyakarta: Universitas Gadjah Mada.
10. Suroto, 2010. Disversifikasi Produk Papan Partikel dari Limbah Serutan Rotan Industri Perajin Rotan. Laporan Penelitian. Baristand Industri Banjarbaru.

11. Setiawan, 2008. Pemanfaatan Limbah Cangkang Kelapa Sawit (Elaeis guineensis Jacq) Dan Plastik Daur Ulang Sebagai Papan Komposit. Skripsi, Departemen Kehutanan Fakultas Pertanian Universitas Sumatera Utara.

12. Maloney TM. (1993). Modern Particleboard and Dry Process Fiberboard Manufacturing. San Fransisco: Miller Freeman Inc 